
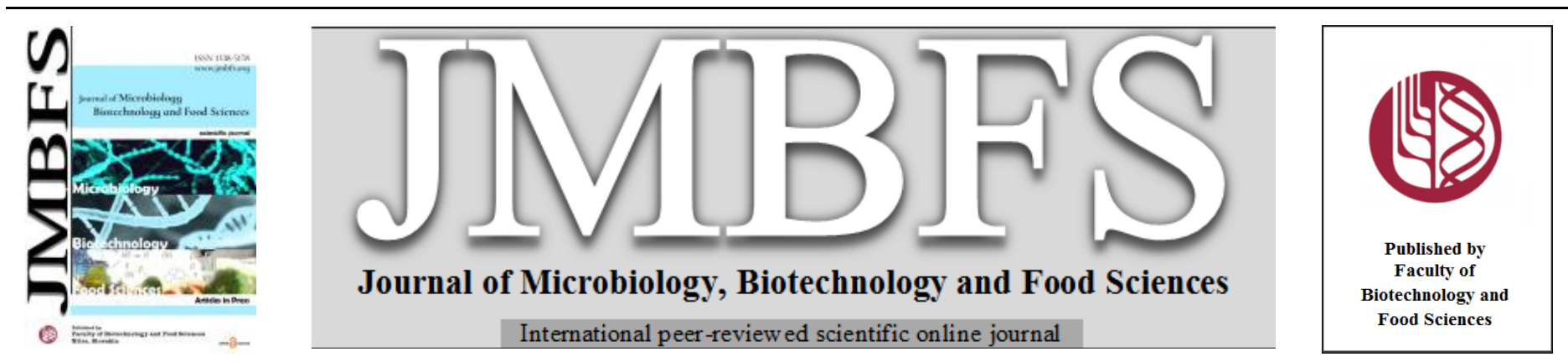

\title{
OPTIMIZATION OF PRICKLY PEAR CACTI (Opuntia spp.) MICROPROPAGATION USING AN EXPERIMENTAL DESIGN METHOD
}

\author{
Achraf Mabrouk ${ }^{1-4}$, Younes Abbas ${ }^{2 *}$, Younes El Goumi ${ }^{1-3}$, Ezzouhra El Maaiden ${ }^{1}$, Youssef El Kharrassi ${ }^{6}$, Salwa EL Antry-Tazi ${ }^{5}$, El \\ Houssine EL Mzouri $^{4}$, Malika Fakiri ${ }^{1}$
}

Address(es):

${ }^{1}$ Laboratory of Agri-food and Health, Faculty of Sciences and Techniques, Hassan 1st University, BP 577, 26000, Settat, Morocco.

${ }^{2}$ Polyvalent Laboratory, Polydisciplinary Faculty, University of Sultan Moulay Slimane, Mghila, BP 592, 23000, Beni Mellal, Morocco.

${ }^{3}$ Laboratory of Phyto-Biotechnology, National Agency for Medicinal and Aromatic Plants, BP 159, Taounate - Morocco.

${ }^{4}$ National Institute of Agronomic Research, Regional Research Centre of Settat, (INRA-CRRA of Settat) BP 589, 26000, Settat, Morocco.

${ }_{6}^{5}$ Forestry Research Center, Ministry of agriculture, Department of Water and Forests, Charia Omar Ibn Al Khattab BP 763, Rabat-Agdal, Morocco.

${ }^{6}$ Laboratory of Biochemistry and Neurosciences, Department of Biology, University Hassan I, BP 577, 26000 Settat, Morocco.

*Corresponding author: a.younes@ usms.ma

https://doi.org/10.15414/jmbfs.1577

\section{ARTICLE INFO}

Received 22. 4. 2019

Revised 18. 6. 2021

Accepted 29. 6. 2021

Published 1. 12. 2021

Regular article open $\partial_{\text {ACCESS }}$

\begin{abstract}
In Morocco, despite the adaptation of the prickly pear cactus (Opuntia spp) to edaphoclimatic conditions, differing from those that prevail in the countries from which it originates, this introduced species is regressing due to biotic and abiotic stresses that impact its survival. Hence, finding innovative technologies to preserve this species are essential. However, the success of in vitro micropropagation technologies is hinged upon the initial disinfection step. In this work we have tested several solutions and exposure time mixtures for disinfection across three different explants, as well as the adoption of hormonal combinations for the induction/regeneration step that allow for efficient micropropagation of cacti. We aimed to produce healthy regenerable vitroplants capable of effectively preserving themselves under aseptic conditions. We describe a specific protocol based on the type of areoles: (1) cladode without areolas (CWA); (2) areolas with shredded glochids (ASG); and (3) areolas with intact glochids (AIG). For each of these areoles, the disinfectant concentration and contact time were optimized and various hormonal combinations were tested for induction/regeneration. The optimal design meeting I-optimality criterion was used to predict the optimal combination by maximizing desirability. The disinfection combination that used $4.23 \%$ calcium hypochlorite (w:v), $0.4 \%$ Tween 20 (v:v), and 10 minutes of exposure time reduced the contamination frequency to $0.002 \%$ with a necrosis rate of less than $0.33 \%$ in explants with AIG. This type was the only one that gave responses in the induction/regeneration phase, which allowed us to predict the best rate of caulogenesis (71.74\%) under a hormonal combination of $5.3 \mathrm{mg} / \mathrm{L}$ of BenzylAminopurine (BAP) and $0.59 \mathrm{mg} / \mathrm{L}$ of 1-Naphthaleneacetic acid (ANA). Furthermore, the highest callogenesis rate of $94.45 \%$ was obtained by a hormonal combination of $6 \mathrm{mg} / \mathrm{L}$ of BAP and $0.59 \mathrm{mg} / \mathrm{L}$ of ANA. The explant's rhizognesis was carried out with a concentration of $0.5 \mathrm{mg} / 1$ ANA, before acclimatization on a substrate containing soil and sand in a ratio of 3:1. In conclusion, these protocols provide easy and cost-effective means to multiply cacti in vitro to preserve them in areas where their culture has been destroyed by cochineal.
\end{abstract}

Keywords: Disinfection, Opuntia Spp, Micropropagation, Contamination, necrosis, ANA/BAP, Optimal design

\section{INTRODUCTION}

The Cactaceae family includes about 130 genera and 1500 species. Among these, the genera Opuntia and Nopalea are the most important because of their uses (Flores-Valdez and Osorio-Gilberto, 1996). The prickly pear (Opuntia spp.) is the most interesting plant in the Cactaceae family, with a worldwide distribution (Pimienta-Barrios, 1994). The Opuntias have a special photosynthetic mechanism known as Crassulacean Acid Metabolism, which makes them able to guarantee the production of large quantities of biomass in arid areas used for livestock feeding (Nobel, 1995; Felker et al., 2006). In the genus Opuntia, Opuntia ficus-indica (barbarica) is a source of edible fruits and cladodes in arid and semi-arid lands (Le Houérou, 1992; Scheinvar, 1995; Juárez and Passera, 2002).

The Opuntias are grown for fruit production and to halt soil erosion in areas of ecological restoration. The low productivity of annual forage crops impacts animal nutrition during the summer season. Therefore, in marginal areas of Morocco, Opuntia clones can be used throughout the year and during critical periods as an alternative for feeding livestock as a standing green forage resource (Boujghagh and Chajia, 2001). The perpetuation of many cactus species in nature is now at risk due to cochineal infestation, overexploitation, and reduction of their natural areas. Several types of cacti are therefore classified as sensitive or in danger of eradication (Mace et al., 1992). Reliable methods for mass propagation of endangered species are highly desirable to satisfy the high demand and, eventually, the restoration of plants in their natural biotope. Cacti are multiplied in most cases by means of seeds or cuttings. However, seeds are often difficult to germinate and when they germinate, plants generally grow slowly (Ault and Blackmon, 1987). Seed spread has several problems, such as genetic segregation, a long juvenile phase, and slow growth of seedlings compared to asexually reproduced plants (Mohamed-Yasseen et al., 1995). Vegetative propagation is the most commonly used. It is done by rooting single or multiple cladodes, small portions of mature cladodes comprising two or more areolas, or using fruit propagules (Estrada-Luna et al., 2008). All of these methods require large spaces and produce a low rate of multiplication. Conversely, modern biotechnologies by cloning or vegetative in vitro propagation (micropropagation) are a pathway that allows rapid multiplication, while preserving the genetic material. The ultimate goal is multiplication in millions of copies of an "elite" plant in a small space.

Depending on the cactus genus, the explants tested for in vitro propagation are different: terminal seedling shoots, vertical or lateral sections of plants or cladodes, and simple areoles. Several reports have been published describing rapid and effective multiplication methods (Johnson and Emino, 1979; Escobar et al., 1986; Smith et al., 1991; Rubluo et al., 1996; García-Saucedo et al., 2005). However, no general protocol is yet available, since most tissue culture responses are highly dependent on the genotype. Therefore, several significant 
modifications and accommodations may need to be made for introduction in a new species or cultivar (García-Saucedo et al., 2005; Estrada-Luna et al., 2008)

In vitro contamination is often the cause of micropropagation failure. Even when strict aseptic conditions are enforced during the in vitro micropropagation process, many plant explants become infected during culture (Cassells, 1986; Boxus and Terzi, 1987; Leifert and Waites, 1990a, 1990b). Epiphytic and endophytic microorganisms are sources for some of these contaminations (Debergh and Vanderschaeghe, 1988; Cassells, 1991; Leifert et al., 1991). In addition, spines and glochids that are normally found in cacti incorporate a wide variety of microorganisms (García-Saucedo et al., 2005). The sterilization process should avoid using high concentrations of disinfectants that may damage plant tissue and low disinfectant concentrations that are unavailing.

In this context, we aimed to develop standardized and effective disinfection protocols specific for each cacti genotype that would guarantee the production of aseptic and regenerant explants.

\section{MATERIAL AND METHODS}

\section{Plant material and initiation of in vitro cultures}

Cacti were collected from different regions of Morocco and grown in the experimental field of Ain Nzagh (CRRA-INRA of Settat). The site is located at an altitude of about $400 \mathrm{~m}$, Lambert coordinates X: 292.413 and Y: 263.664 (Mabrouk et al., 2016). The cladodes of Opuntia ficus indica were harvested from this site and were the subject of experiments on disinfection and in vitro culture.

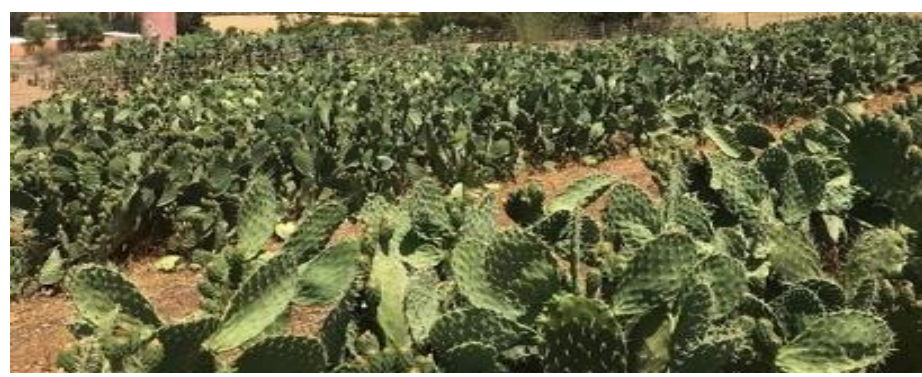

Figure 1 Experimental field of Ain Nzagh (CRRA-INRA of Settat)

\section{Disinfection protocol}

Depending on the cladode's type, different combinations of calcium hypochlorite, Tween 20 , and time were tested. For this purpose, various explants were used to evaluate the decontamination ability of the adopted protocols. Decontamination was based on the mixture of hypochlorite and Tween 20 as a disinfection solution in a specific period of time and 3 types of explants were distinguished according to the type of areolas (absence, presence, and areolas shredded).

\section{$>$ Explant 1: Cladodes without areoles (CWA)}

Areoles including the glochids were completely removed using a sterile scalpel in an aseptic environment under a laminar flow hood.

$>\quad$ Explant 2: Areoles with shredded glochids (ASG)

The glochids were slightly shredded to allow the disinfection solution to reach inside the areolas.

> Explant 3: areoles with intact glochids (AIG)

This protocol consisted of leaving the areolas intact without modifying the entire cladode.

\section{Disinfection method}

The cladodes were rinsed under running water for $5 \mathrm{~min}$ and dried with a sterile cloth under a laminar flow hood. Then, the explant types described above were dipped in a mixture of calcium hypochlorite and Tween 20 for 10 to 20 minutes. The choice of the calcium hypochlorite, Tween 20 , and time ratio mixture design adopted in our experiments was performed by the software SAS Institute Inc. 2018. JMP ${ }^{\circledR} 14$ Design of Experiments Guide. Cary, NC: SAS Institute Inc.

\section{Plant tissue culture}

The disinfected cladodes were cut into pieces of $1.0 \mathrm{~cm}^{2}$ as fragments ready for micropropagation (Figure 2).
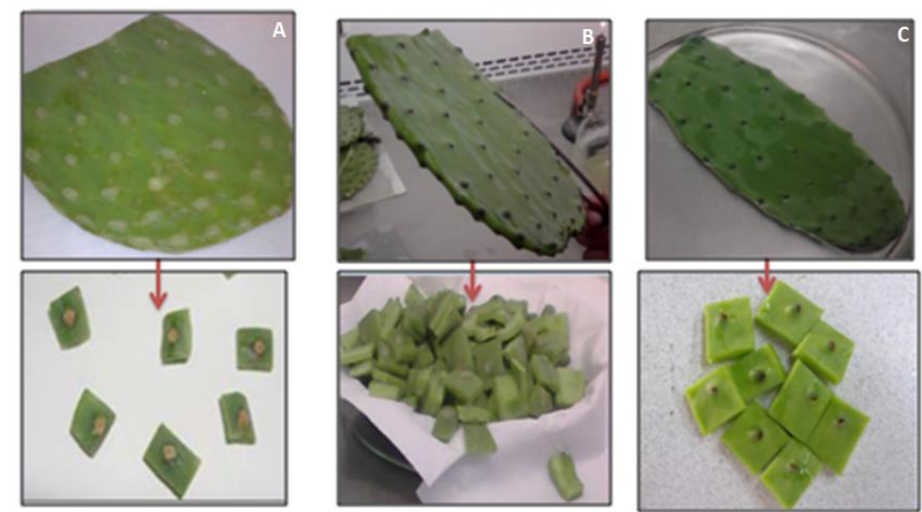

Figure 2 Types of explants to be disinfected prior to in vitro culture. A: Explan 1: Cladodes without areoles (CWA); B: Explant 2: Areoles with shredded glochids (ASG); C: Explant 3: Areoles with intact glochids (AIG).

The explants were cultured on a Murashige and Skoog induction medium (Murashige and Skoog, 1962) in Petri dishes of $90 \mathrm{~mm}$ diameter. The medium was supplemented by $3 \%$ sucrose and $0.1 \%$ activated charcoal. Various hormonal combinations were added to the medium as described in Table 2. Solidification was ensured by adding $0.7 \%$ vegetable agar to the medium. The medium's $\mathrm{pH}$ was adjusted between 5.5 and 5.7 with $\mathrm{HCl}$ or $\mathrm{NaOH}$, and autoclaved at $121^{\circ} \mathrm{C}$ and 1 bar of pressure for 15 minutes.

Table 2 Hormonal combinations of 1-Naphthaleneacetic acid (ANA) and 6BenzylAminopurine (BAP).

\begin{tabular}{l|l|l|l|l|l|l|l|l|l|l|l|l|l}
\hline BAP mg /l & 0 & \multicolumn{3}{|c|}{1.5} & \multicolumn{3}{c|}{3} & \multicolumn{3}{c|}{4,5} & \multicolumn{3}{|c|}{6} \\
\hline $\begin{array}{l}\text { ANA } \\
\text { mg/L }\end{array}$ & 0 & 0 & 0.5 & 1 & 0 & 0.5 & 1 & 0 & 0.5 & 1 & 0 & 0.5 & 1 \\
\hline
\end{tabular}

Petri dishes were inoculated with 5 explants and incubated in a growth chamber maintained at $25^{\circ} \mathrm{C} \pm 2^{\circ} \mathrm{C}$. The photoperiod was $16 \mathrm{~h}$ light and $8 \mathrm{~h}$ darkness. The control of the explants and observations were performed daily.

\section{Rooting of shoots}

To stimulate rhizogenesis, the shoots developed during induction were transferred to an MS rooting medium (Murashige and Skoog, 1962), supplemented with $0.5 \mathrm{mg} / 1$ of ANA, $3 \%$ sucrose, $0.1 \%$ activated charcoal, and solidified with $0.7 \%$ vegetable agar. The $\mathrm{pH}$ was adjusted to $5.5 \pm 0.2$ before autoclaving.

\section{Acclimatization}

The rooted vitroplants were washed under tap water to remove the adherent gel and then acclimatized in plastic pots containing an autoclaved homogenate of potting soil and sand at a ratio of $3: 1$.

\section{Experimental design method and statistical analyses}

The optimization approach using the experimental design method followed during this study adopted the I-optimal design that minimized the average variance of prediction over the design space. I-optimality criterion was more appropriate to do the following (SAS, 2018):

1. Predict a response;

2. Determine optimum operating conditions by maximizing the desirability;

3. Determine regions in the design space where the response falls within an acceptable range.

In our case, precise prediction of the response took precedence over precise estimation of the parameters. For the disinfection phase, the optimal experimenta design consisted of 12 randomized combinations of three factors (Hypochlorite, Tween-20, and Time) without replication (Table 4). For the rate of caulogenesis and callogenesis, we adopted a custom design comprising 13 randomized hormonal combinations of ANA (ranging from 0 to $1 \mathrm{mg} / \mathrm{L}$ ) and BAP (from 0 to $6 \mathrm{mg} / \mathrm{L}$ ) with three replications, responses were recorded and analyzed.

The data were statistically processed by an analysis of variance (ANOVA) F-test. The comparison of averages was performed by Student's t-test. The experimental design and the analyses were carried out using the JMP SAS software (JMP ${ }$, Version <12>. SAS Institute Inc. 2015). Differences were considered significant at $\mathrm{P}=0.05$. 


\section{RESULTS}

Cacti explants sterilization is a key step before successful in vitro culture Designing a disinfection protocol to provide the most sterile explants ensures their survival during in vitro culture.

\section{Contamination and necrosis rates}

The results revealed that the contamination $(\mathrm{Ct})$ rate was significantly influenced by the explant, in contrast to the necrosis (Nc) rate that was not significantly affected (Table 3 ).

Table 3 ANOVA results to test for differences in contamination and necrosis rates across different explants

\begin{tabular}{|c|c|c|c|c|c|c|c|c|c|}
\hline \multirow[b]{2}{*}{ Source } & \multirow[b]{2}{*}{ DF } & \multicolumn{2}{|l|}{ Sum of Squares } & \multicolumn{2}{|c|}{ Mean Square } & \multicolumn{2}{|c|}{ F Ratio } & \multicolumn{2}{|c|}{ Prob $>$ F } \\
\hline & & $\begin{array}{l}\text { Contamination } \\
\text { rate }\end{array}$ & $\begin{array}{l}\text { Necrosis } \\
\text { rate }\end{array}$ & $\begin{array}{c}\text { Contamination } \\
\text { rate }\end{array}$ & $\begin{array}{c}\text { Necrosis } \\
\text { rate }\end{array}$ & $\begin{array}{c}\text { Contamination } \\
\text { rate }\end{array}$ & $\begin{array}{c}\text { Necrosis } \\
\text { rate }\end{array}$ & $\begin{array}{c}\text { Contamination } \\
\text { rate }\end{array}$ & $\begin{array}{c}\text { Necrosis } \\
\text { rate }\end{array}$ \\
\hline Explant & 2 & 1467,56 & 440,89 & 733,78 & 220,44 & 14,3452 & 1,7114 & $<, 0001 *$ & $0,1963^{\mathrm{ns}}$ \\
\hline Model & 2 & 1467,56 & 440,89 & 733,78 & 220,44 & 14,3452 & & $<, 0001^{*}$ & $0,1963^{\mathrm{ns}}$ \\
\hline Error & 33 & 1688,00 & 4250,67 & 51,15 & 128,81 & 1,7114 & & & \\
\hline C. Total & 35 & 3155,56 & 4691,56 & & & & & & \\
\hline
\end{tabular}

* and ns: significant at $0.1 \%$ level and ns: not significant at $5 \%$, respectively. DF: Degree of freedom

When Explant 1 (CWA) and Explant 2 (ASG) were applied, the average contamination rates were high reaching 15.33 and $11.67 \%$, respectively. However, the contamination rate significantly dropped to $0.33 \%$ when Explant 3 (AIG) was used. Similarly, average necrosis rates were high when Explant 1
(CWA) (10\%) and Explant 2 (ASG) (8.67\%) were used. Using Explant 3 (AIG) provided the lowest rates, which did not exceed $2 \%$ (Table 4 ).

Table 4 Experimental matrix with 12 combinations and observed responses of contamination and necrosis rate in the three protocols.

\begin{tabular}{|c|c|c|c|c|c|c|c|c|}
\hline \multicolumn{3}{|l|}{ Factors } & \multicolumn{2}{|c|}{$\begin{array}{c}\text { Explant } \\
\text { CWA }\end{array}$} & \multicolumn{2}{|c|}{$\begin{array}{c}\text { Explant } \\
\text { ASG }\end{array}$} & \multicolumn{2}{|c|}{$\begin{array}{c}\text { Explant } \\
\text { AIG }\end{array}$} \\
\hline Hypochlorite & Tween & Temps & $\begin{array}{c}\text { Contamination } \\
\% \\
\end{array}$ & Necrosis \% & $\begin{array}{c}\begin{array}{c}\text { Contaminati } \\
\text { on } \%\end{array} \\
\end{array}$ & Necrosis \% & $\begin{array}{c}\text { Contamina } \\
\text { tion } \%\end{array}$ & Necrosis \% \\
\hline 1 & 0,2 & 20 & 12 & 0 & 4 & 0 & 0 & 0 \\
\hline 1 & 0,8 & 10 & 16 & 0 & 16 & 4 & 0 & 0 \\
\hline 1,5 & 0 & 15 & 20 & 0 & 24 & 12 & 4 & 0 \\
\hline 1,5 & 1 & 15 & 12 & 0 & 12 & 4 & 0 & 0 \\
\hline 2,5 & 0,2 & 10 & 4 & 32 & 8 & 4 & 0 & 0 \\
\hline 2,5 & 0,8 & 20 & 12 & 20 & 28 & 4 & 0 & 0 \\
\hline 4,5 & 0,4 & 15 & 24 & 48 & 0 & 4 & 0 & 4 \\
\hline 4,5 & 0,6 & 15 & 12 & 8 & 4 & 0 & 0 & 0 \\
\hline 5,5 & 0 & 10 & 24 & 8 & 8 & 8 & 0 & 12 \\
\hline 5,5 & 1 & 20 & 12 & 0 & 28 & 4 & 0 & 0 \\
\hline 6 & 0,2 & 20 & 28 & 4 & 4 & 40 & 0 & 8 \\
\hline 6 & 0,8 & 10 & 8 & 0 & 4 & 20 & 0 & 0 \\
\hline Average & & & $15,33 \pm 2,08 A$ & $10,00 \pm 4,50 A$ & $11,67 \pm 2,89 A$ & $8,67 \pm 3,26 A$ & $0,33 \pm 0,33 B$ & $2,00 \pm 1,15 \mathrm{~A}$ \\
\hline
\end{tabular}

For the same parameter, means linked with the same letter were not significantly different at $p=0.05$. The average is presented through the means $( \pm \mathrm{SE})$.

\section{Prediction of optimal disinfection mixture}

Using a prediction profiler (Figure 3), we selected the combination of calcium hypochlorite:Tween 20 and disinfection time for each explant type that would most efficiently minimize contamination rates. Using Explant CWA, lowest average contamination $(0.77 \%)$ was obtained by a combination of $3.5 \% \mathrm{Ca}(\mathrm{ClO})_{2}$ and $0.5 \%$ Tween 20 for 10 minutes. Conversely, for the explant ASG, the combination of $4.6 \% \mathrm{Ca}(\mathrm{ClO})_{2}$ and $0.44 \%$ Tween 20 for 15 minutes generated the lowest average of contamination $(0.064 \%)$. Using Explant ASG and a combination of $4.23 \%$ of $\mathrm{Ca}(\mathrm{ClO})_{2}$ and $0.4 \%$ Tween 20 for 10 minutes, lowered the contamination rates to less than $0.002 \%$ (Figure 4, Table 4).

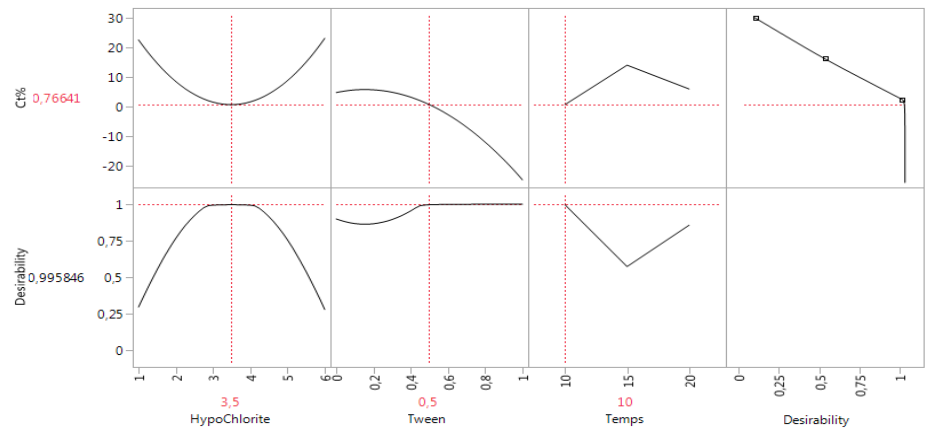

Explant CWA
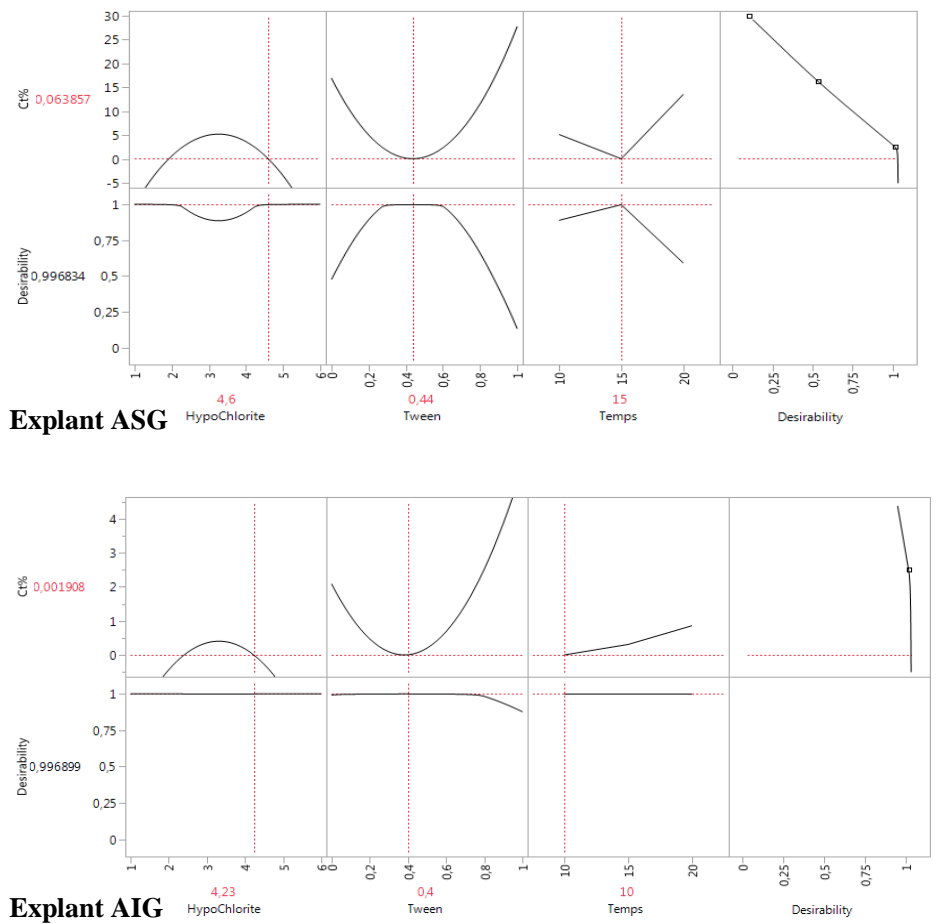

Figure 3 Prediction profiler for disinfection mixture components with the optimal setting and maximum desirability for the three types of explants. 
Table 4 Desirability of explant types according to optimal combinations $\left(\mathrm{Ca}(\mathrm{ClO})_{2}\right.$ - Tween 20 - duration of treatment $)$.

\begin{tabular}{l|ccc}
\hline \multirow{2}{*}{ Parameters } & \multicolumn{3}{c}{ Explant } \\
\cline { 2 - 4 } & CWA & ASG & AIG \\
\hline Ca(ClO) $\mathbf{2}(\%)$ & 3,5 & 4,6 & 4,23 \\
Tween 20 (\%) & 0,5 & 0,44 & 0,4 \\
Time (min) & 10 & 15 & 10 \\
Contamination \% minimum & 0,77 & 0,064 & 0,002 \\
\hline Desirability & 0,996 & 0,997 & $\mathbf{0 , 9 9 7}$ \\
Average response & 15,33 & 11,67 & $\mathbf{0 , 3 3}$ \\
Observations (or weighted sums) & 12 & 12 & 12 \\
\hline
\end{tabular}

\section{Interaction effect between explant and hormonal combination}

The results revealed that caulogenesis and callogenesis rates were significantly influenced by the explant and hormonal combinations. These responses were significant in explant and hormonal combinations interaction, indicating that the responses to give shoots and callus were variable among explants and hormonal combinations (Table 5).

Table 5 Analysis of variance (ANOVA) for caulogenesis and callogenesis rates according to different explants and hormonal combinations.

\begin{tabular}{|c|c|c|c|c|c|c|c|c|c|}
\hline \multirow[b]{2}{*}{ Source } & \multirow[b]{2}{*}{ DF } & \multicolumn{2}{|c|}{ Sum of Squares } & \multicolumn{2}{|c|}{ Mean Square } & \multicolumn{2}{|c|}{ F Ratio } & \multicolumn{2}{|c|}{ Prob > F } \\
\hline & & $\begin{array}{c}\text { Caulogenesis } \\
\text { rate }(\%)\end{array}$ & $\begin{array}{c}\text { Callogenesis } \\
\text { rate }(\%)\end{array}$ & \begin{tabular}{|c|}
$\begin{array}{c}\text { Caulogenesis } \\
\text { rate }(\%)\end{array}$ \\
\end{tabular} & $\begin{array}{c}\text { Callogenesis } \\
\text { rate }(\%)\end{array}$ & $\begin{array}{c}\text { Caulogenesis } \\
\text { rate }(\%)\end{array}$ & $\begin{array}{c}\text { Callogenesis } \\
\text { rate }(\%)\end{array}$ & $\begin{array}{c}\text { Caulogenesis } \\
\text { rate }(\%)\end{array}$ & $\begin{array}{c}\text { Callogenesis } \\
\text { rate }(\%)\end{array}$ \\
\hline Explant (Ex) & 2 & 23600,43 & 55384,62 & 11800,21 & 27692,31 & 1009,967 & 767,4088 & $<, 0001 *$ & $<, 0001 *$ \\
\hline $\begin{array}{l}\text { Combinations } \\
\text { (Cb) }\end{array}$ & 12 & 10213,68 & 18002,14 & 851,14 & 1500,18 & 72,8481 & 41,5729 & $<, 0001^{*}$ & $<, 0001^{*}$ \\
\hline $\mathrm{Ex} * \mathrm{Cb}$ & 24 & 20427,35 & 36004,27 & 851,14 & 1500,18 & 72,8481 & 41,5729 & $<, 0001^{*}$ & $<, 0001^{*}$ \\
\hline Model & 38 & 54241,45 & 109391,03 & 1427,41 & 2878,71 & 122,1701 & 79,7748 & $<, 0001^{*}$ & $<, 0001^{*}$ \\
\hline Error & 78 & 911,33 & 2814,67 & 11,68 & 36,09 & & & & \\
\hline
\end{tabular}

\begin{tabular}{llll}
\hline C. Total & 116 & 55152,79 & 112205,69
\end{tabular}

* : significant at $0.1 \%$ level. DF: Degree of freedom

Cacti explants disinfected using explant (CWA), explant (ASG), and cultured in vitro for 3 weeks did not produce calli or buds. In contrast, explant (AIG) had a caulogenic response with buds visible in $30.13 \%$ of the explants, while the callogenic response allowed for callus formation in $46.10 \%$ of the cultured explants (Table 6 and Figure 4).

Table 6 Caulogenesis and callogenesis rate depending on the adopted protocols

\begin{tabular}{|c|c|c|c|c|c|c|c|c|c|c|}
\hline \multirow{3}{*}{ Combinations } & \multirow{2}{*}{\multicolumn{2}{|c|}{ Hormones }} & \multicolumn{6}{|l|}{ Explant } & \multirow{2}{*}{\multicolumn{2}{|c|}{ Average }} \\
\hline & & & \multicolumn{2}{|l|}{ CWA } & \multicolumn{2}{|l|}{ ASG } & \multicolumn{2}{|l|}{ AIG } & & \\
\hline & $\begin{array}{l}\text { BAP } \\
(\mathbf{m g} / \mathbf{L})\end{array}$ & $\begin{array}{l}\text { ANA } \\
(\mathrm{mg} / \mathrm{L})\end{array}$ & \begin{tabular}{|l|} 
Caulogenesis \\
rate $(\%)$
\end{tabular} & $\begin{array}{l}\text { Callogenesis } \\
\text { rate }(\%)\end{array}$ & $\begin{array}{l}\text { Caulogenesis } \\
\text { rate }(\%)\end{array}$ & $\begin{array}{l}\text { Callogenesis } \\
\text { rate }(\%)\end{array}$ & $\begin{array}{l}\text { Caulogenesis } \\
\text { rate }(\%)\end{array}$ & $\begin{array}{l}\text { Callogenesis } \\
\text { rate }(\%)\end{array}$ & $\begin{array}{l}\text { Caulogenesis } \\
\text { rate (\%) }\end{array}$ & $\begin{array}{l}\text { Callogenesis } \\
\text { rate }(\%)\end{array}$ \\
\hline $\mathrm{C} 1$ & 0 & 0 & $0,00 \pm 0,00^{\mathbf{f}}$ & $0,00 \pm 0,00^{\mathrm{f}}$ & $0,00 \pm 0,00^{\mathbf{f}}$ & $0,00 \pm 0,00^{\mathbf{f}}$ & $0,00 \pm 0,00^{\mathbf{f}}$ & $0,00 \pm 0,00^{\mathbf{f}}$ & $0,00 \pm 0,00^{d}$ & $0,00 \pm 0,00^{\mathbf{f}}$ \\
\hline $\mathrm{C} 2$ & 1,5 & 0 & $0,00 \pm 0,00^{\mathbf{f}}$ & $0,00 \pm 0,00^{\mathbf{f}}$ & $0,00 \pm 0,00^{\mathbf{f}}$ & $0,00 \pm 0,00^{\mathbf{f}}$ & $0,00 \pm 0,00^{\mathbf{f}}$ & $25,00 \pm 1,15^{\mathrm{e}}$ & $0,00 \pm 0,00^{\mathbf{d}}$ & $8,33 \pm 4,18^{\mathrm{e}}$ \\
\hline C3 & 1,5 & 0,5 & $0,00 \pm 0,00^{\mathbf{f}}$ & $0,00 \pm 0,00^{\mathbf{f}}$ & $0,00 \pm 0,00^{\mathbf{f}}$ & $0,00 \pm 0,00^{\mathbf{f}}$ & $50,00 \pm 5,57^{\mathrm{c}}$ & $91,67 \pm 2,40^{\mathrm{a}}$ & $16,67 \pm 8,49^{\mathbf{b}}$ & $30,56 \pm 15,29^{\mathrm{ab}}$ \\
\hline $\mathrm{C} 4$ & 1,5 & 1 & $0,00 \pm 0,00^{\mathbf{f}}$ & $0,00 \pm 0,00^{\mathbf{f}}$ & $0,00 \pm 0,00^{\mathbf{f}}$ & $0,00 \pm 0,00^{\mathbf{f}}$ & $8,33 \pm 1,20^{\mathrm{e}}$ & $0,00 \pm 0,00^{\mathbf{f}}$ & $2,78 \pm 1,43^{\mathrm{d}}$ & $0,00 \pm 0,00^{\mathbf{f}}$ \\
\hline C5 & 3 & 0 & $0,00 \pm 0,00^{\mathbf{f}}$ & $0,00 \pm 0,00^{\mathrm{f}}$ & $0,00 \pm 0,00^{\mathbf{f}}$ & $0,00 \pm 0,00^{\mathbf{f}}$ & $25,00 \pm 1,00^{\mathrm{d}}$ & $41,67 \pm 3,28^{\mathrm{d}}$ & $8,33 \pm 4,18^{c}$ & $13,89 \pm 7,01^{\text {de }}$ \\
\hline C6 & 3 & 0,5 & $0,00 \pm 0,00^{\mathbf{f}}$ & $0,00 \pm 0,00^{\mathbf{f}}$ & $0,00 \pm 0,00^{\mathbf{f}}$ & $0,00 \pm 0,00^{\mathbf{f}}$ & $50,00 \pm 7,21^{\mathrm{c}}$ & $0,00 \pm 0,00^{\mathbf{f}}$ & $16,67 \pm 8,59^{\mathbf{b}}$ & $0,00 \pm 0,00^{\mathbf{f}}$ \\
\hline C7 & 3 & 1 & $0,00 \pm 0,00^{\mathbf{f}}$ & $0,00 \pm 0,00^{\mathbf{f}}$ & $0,00 \pm 0,00^{\mathbf{f}}$ & $0,00 \pm 0,00^{\mathbf{f}}$ & $25,00 \pm 2,65^{\mathrm{d}}$ & $58,33 \pm 6,89^{\mathbf{c}}$ & $8,33 \pm 4,24^{\mathrm{c}}$ & $19,44 \pm 9,92^{\text {cd }}$ \\
\hline $\mathrm{C} 8$ & 4,5 & 0 & $0,00 \pm 0,00^{\mathbf{f}}$ & $0,00 \pm 0,00^{\mathbf{f}}$ & $0,00 \pm 0,00^{\mathbf{f}}$ & $0,00 \pm 0,00^{\mathbf{f}}$ & $0,00 \pm 0,00^{\mathbf{f}}$ & $0,00 \pm 0,00^{\mathbf{f}}$ & $0,00 \pm 0,00^{\mathrm{d}}$ & $0,00 \pm 0,00^{\mathbf{f}}$ \\
\hline C9 & 4,5 & 0,5 & $0,00 \pm 0,00^{\mathbf{f}}$ & $0,00 \pm 0,00^{\mathbf{f}}$ & $0,00 \pm 0,00^{\mathbf{f}}$ & $0,00 \pm 0,00^{\mathbf{f}}$ & $75,00 \pm 3,46^{\mathbf{b}}$ & $100,00 \pm 1,15^{\mathrm{a}}$ & $25,00 \pm 12,54^{\mathrm{a}}$ & $33,33 \pm 16,67^{\mathrm{a}}$ \\
\hline $\mathrm{C} 10$ & 4,5 & 1 & $0,00 \pm 0,00^{\mathbf{f}}$ & $0,00 \pm 0,00^{\mathbf{f}}$ & $0,00 \pm 0,00^{\mathbf{f}}$ & $0,00 \pm 0,00^{\mathbf{f}}$ & $50,00 \pm 4,36^{\mathbf{c}}$ & $75,00 \pm 4,04^{b}$ & $16,67 \pm 8,43^{b}$ & $25,00 \pm 12,55^{\mathrm{bc}}$ \\
\hline $\mathrm{C} 11$ & 6 & 0 & $0,00 \pm 0,00^{\mathbf{f}}$ & $0,00 \pm 0,00^{\mathbf{f}}$ & $0,00 \pm 0,00^{\mathbf{f}}$ & $0,00 \pm 0,00^{\mathbf{f}}$ & $0,00 \pm 0,00^{\mathbf{f}}$ & $58,33 \pm 6,01^{\mathbf{c}}$ & $0,00 \pm 0,00^{d}$ & $19,44 \pm 9,88^{\mathrm{cd}}$ \\
\hline $\mathrm{C} 12$ & 6 & 0,5 & $0,00 \pm 0,00^{\mathbf{f}}$ & $0,00 \pm 0,00^{\mathrm{f}}$ & $0,00 \pm 0,00^{\mathbf{f}}$ & $0,00 \pm 0,00^{\mathbf{f}}$ & $83,33 \pm 4,63^{\mathrm{a}}$ & $100,00 \pm 13,23^{\mathbf{a}}$ & $27,78 \pm 13,95^{\mathrm{a}}$ & $33,33 \pm 17,10^{\mathrm{a}}$ \\
\hline $\mathrm{C} 13$ & 6 & 1 & $0,00 \pm 0,00^{\mathbf{f}}$ & $0,00 \pm 0,00^{\mathbf{f}}$ & $0,00 \pm 0,00^{\mathbf{f}}$ & $0,00 \pm 0,00^{\mathbf{f}}$ & $25,00 \pm 2,65^{\mathrm{d}}$ & $50,00 \pm 13,23^{\mathrm{cd}}$ & $8,33 \pm 4,24^{\mathrm{c}}$ & $16,67 \pm 9,17^{\mathrm{d}}$ \\
\hline Average & & & $0,00 \pm 0,00^{b}$ & $0,00 \pm 0,00^{b}$ & $0,00 \pm 0,00^{b}$ & $0,00 \pm 0,00^{b}$ & $30,13 \pm 4,61^{\mathrm{a}}$ & $46,15 \pm 6,19^{a}$ & $10,04 \pm 2,02$ & $15,38 \pm 2,88$ \\
\hline
\end{tabular}

For the same parameter, means linked with the same letter were not significantly different at $p=0.05$. Data are presented through the means ( \pm SE). 


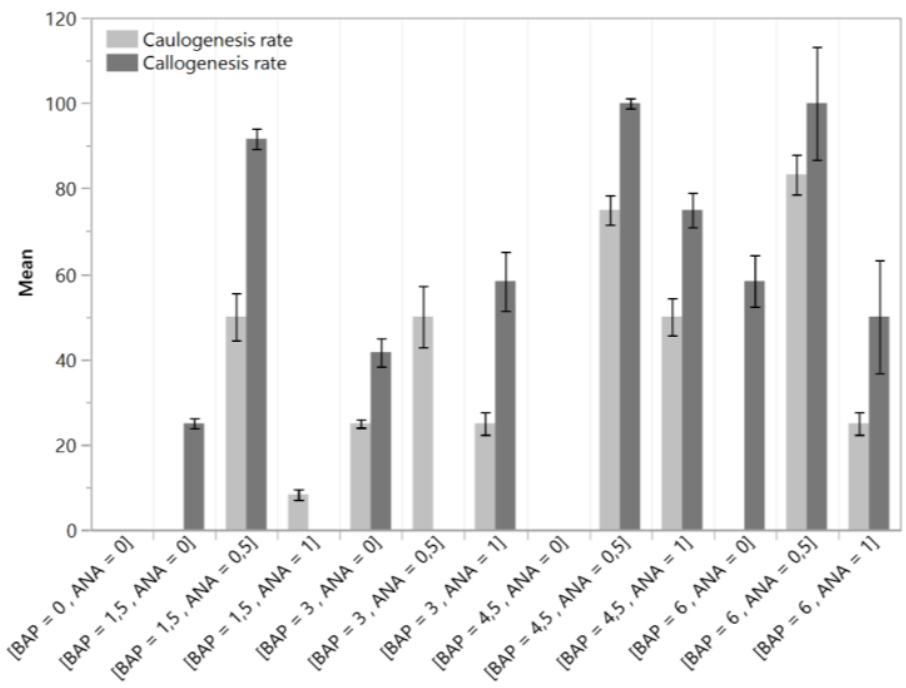

Hormonal Combinations ( $\mathrm{mg} / \mathrm{L}$ )

Figure 4 Data of mean effect of each type of explants on the rate of caulogenesis and callogenesis.

\section{Prediction of the optimal hormonal combination auxin/cytokinin}

Only explant outcomes from Explant 3 (AIG) were used for micropropagation. The optimization of this phase aimed to maximize caulogenic and callogenic responses by identifying the best ANA / BAP combinations.

Using a prediction profiler, we selected the optimal hormonal combination of 5.3 $\mathrm{mg} / \mathrm{L} \mathrm{BAP}$ and $0.59 \mathrm{mg} / \mathrm{L}$ ANA as being the one that would produce the highest rate of caulogenesis (71.74\%). The highest callogenesis rate of $94.45 \%$ was predicted to be obtained when using a hormonal combination of $6 \mathrm{mg} / \mathrm{L}$ of $\mathrm{BAP}$ and $0.59 \mathrm{mg} / \mathrm{L}$ of ANA (Figure 5). The neoformed buds led to the formation of complete vitroplants after 5 weeks (Figure 6), which were then transferred to a rooting medium to stimulate rhizogenesis (Figure 7) and finally acclimated so that they would be susceptible to be transferred to the fields (Figure 8).
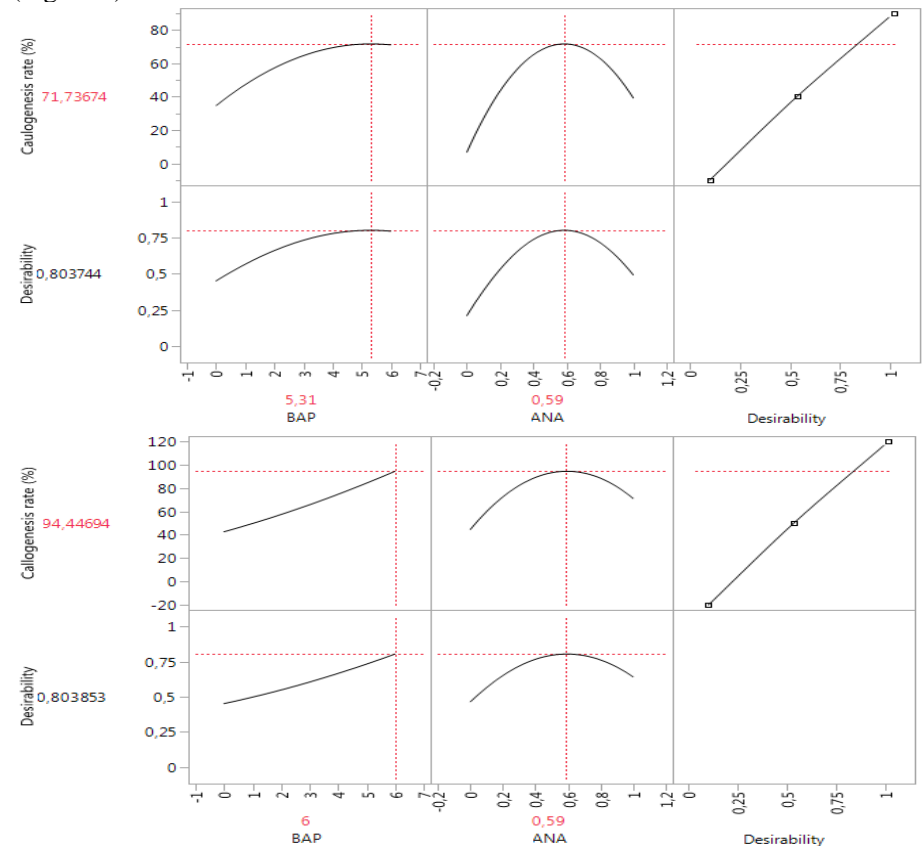

Figure 5 Predictive profiler of best hormonal combinations of ANA and BAP for optimal caulogenesis and callogenesis response.

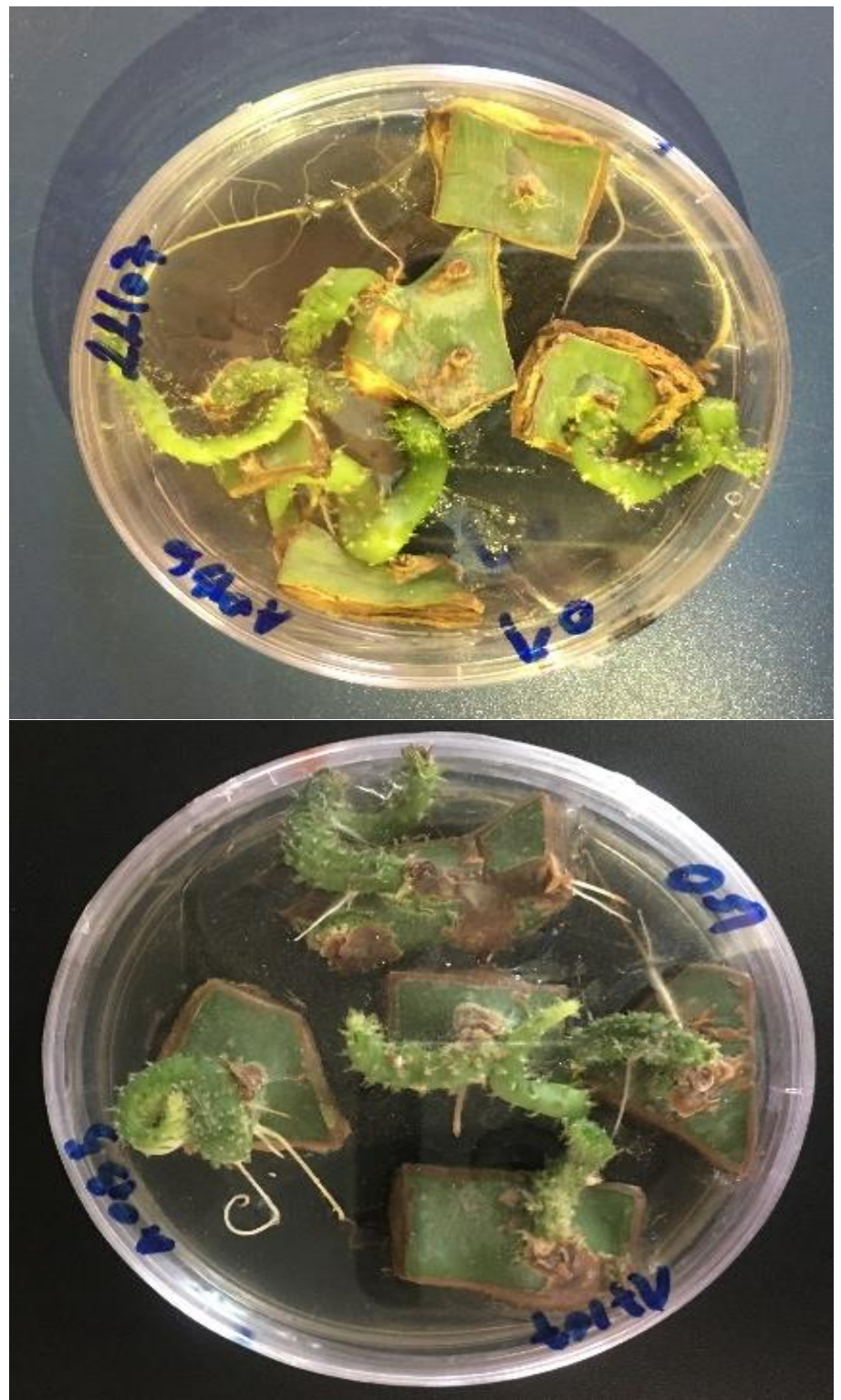

Figure 6 Buds produced by protocol 3 during induction

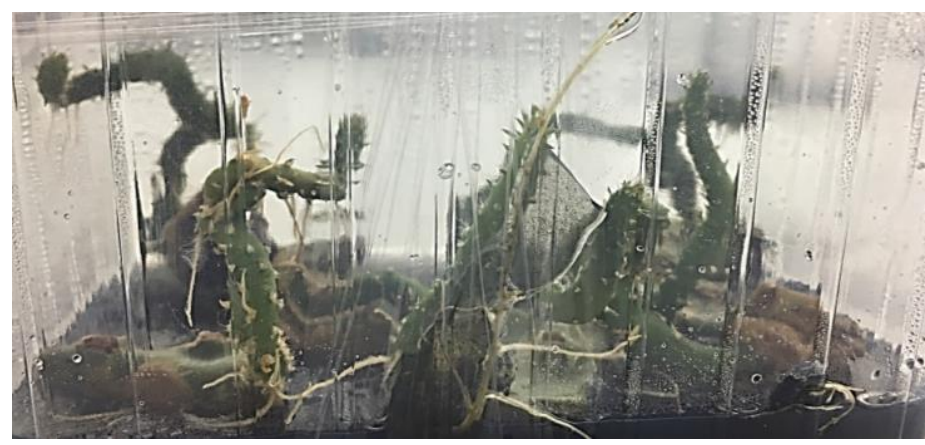

Figure 7 Explants of cacti transferred to a rooting medium

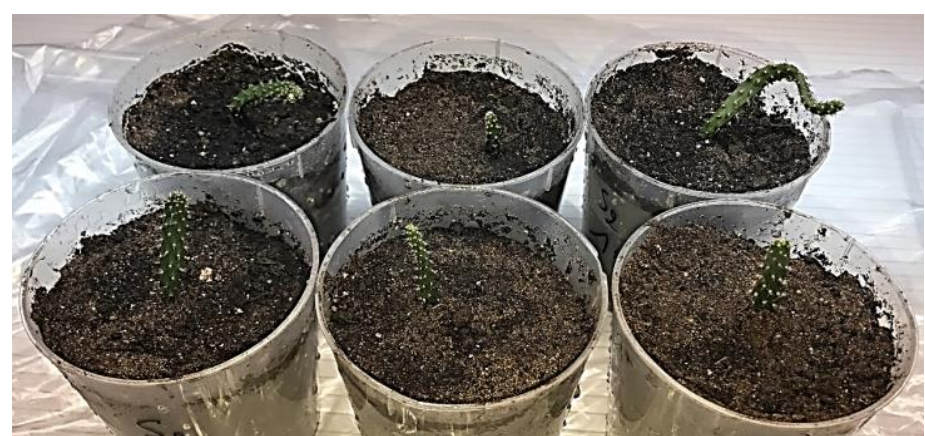

Figure 8 Explants of cacti transferred on an acclimation substrate 


\section{DISCUSSION}

Cacti (Opuntias) micropropagation can be achieved if a reliable and reproducible disinfection method is standardized to obtain non-necrotic healthy and regenerable explants. Disinfection protocols described in the literature for Opuntias (Escobar et al., 1986; Palomino et al., 1999) are diverse but the majority of these use $70 \%$ ethanol, absolute ethanol, $\mathrm{Ca}(\mathrm{ClO})_{2}$, or commercial bleach. We have applied several of these protocols to our explants, but we lost all of the explants we cultured because of necrosis and persisting contaminations. In other research, (Katja et al., 2003; Aliyu and Mustapha, 2007; Khalafalla $e t$ al., 2007; Ramirez-Malagon et al., 2007; Ghaffari et al., 2013), the use of high concentrations of the disinfectant may alter the cellular response of explants after disinfection. We have also tried the protocol adopted by (Ghaffari et al., 2013), using 5\% sodium hypochlorite and $0.1 \%$ tween 20 for $15 \mathrm{~min}$ for the disinfection of cladodes of Opuntia ficus-indica, but we lost those explants to necrosis. Similarly, we tested the sterilization protocol used by (Clayton et al., 1990; De Oliveira et al., 1995; Eugenio and Carlos Antonio, 2002; Giusti et al., 2002; De Medeiros et al., 2006), that consisted of ethanol and $\mathrm{Ca}(\mathrm{ClO})_{2}$ from 0.25 to $6 \%$; this protocol allowed us to notice a clear decrease in the contamination rate, but the necrosis rate remained high, ranging from 80 to $100 \%$.

Indeed, it had been suggested that the addition of a few drops of Tween 20 to a disinfecting solution based on $\mathrm{Ca}(\mathrm{ClO})_{2}$ allowed better contact of the sterilizing agent with the treated surfaces and protected against damage of the plant tissue (Dabekaussen et al., 1991; Karimi et al., 2010).

After identifying the products to be used, including $\mathrm{Ca}(\mathrm{ClO})_{2}$ and Tween 20 , and after observing that contaminations always started at the areolas, which are a host to a wide variety of microorganisms (García-Saucedo et al., 2005), 3 types of explants were distinguished according to the type of areolas [absence, presence, and areolas shredded; Explant 1: Cladodes without areoles (CWA), Explant 2: Areoles with shredded glochids (ASG), and Explant 3: areoles with intact glochids (AIG), respectively], to highlight the role of glochids in the preservation of the meristematic tissue.

Additionally, the combination of sterilant concentrations with the duration of treatment and hence the explant producibility and regeneration in the various hormonal combinations were tested. The results of this study showed that the concentrations of $\mathrm{Ca}(\mathrm{ClO})_{2}$ and Tween 20 obtained for the three type of explants were quite similar. They varied between 3.5 and $4.6 \%$ for $\mathrm{Ca}(\mathrm{ClO})_{2}$ and from 0.4 to $0.5 \%$ for Tween 20 . The best disinfection results were obtained by adopting Explant 3 (AIG) with $4.23 \% \mathrm{Ca}(\mathrm{ClO})_{2}$ and $0.4 \%$ tween 20 for a duration of 10 min. The rate of contamination and necrosis was almost zero $(0.002 \%)$ and therefore, the explants were healthy and completely disinfected.

Explant 3 (AIG), achieved with intact areoles and glochids, yielded very convincing results from the $3^{\text {rd }}$ week of culture and complete vitroplants after the $5^{\text {th }}$ week. Compared with current research in this field, the results indicate a time interval of 4 to 12 weeks (Ramirez-Malagon et al., 2007; Karimi et al., 2010; El Finti et al., 2012; Ghaffari et al., 2013). In addition, the failure of Explant 1 (CWA) and Explant 2 (ASG) could be explained by the role of glochids in the protection and preservation of meristematic tissue against damage caused by disinfectants.

In our study, concentrations of $5 \mathrm{mg} / 1 \mathrm{BAP}$ in combination with $0.5 \mathrm{mg} / 1$ ANA led to the formation of a large number of shoots. This result is in agreement with the results obtained in previous research (Jaiswal and Amin, 1987; MartínezVázquez and Rubluo, 1989; Mohamed-Yasseen et al., 1995; De Medeiros et al., 2006; Khalafalla et al., 2007; Estrada-Luna et al., 2008; El Finti et al., 2012).

This study indicated that the best method for cacti explant disinfection was when $\mathrm{Ca}(\mathrm{ClO})_{2}$ was combined with Tween 20 for 10 minutes in the case of Explant 3 (AIG). In addition, precise combinations of BAP associated with ANA induced caulogenesis and callogenesis with the highest rate occurring after the 3rd week under controlled conditions. Optimization was applied for other species of cacti and they highlight promising results (data not published). This protocol made it possible to guarantee the survival of cactus explants during micropropagation and thus, made it possible to produce large quantities of plants having the desired specificities. It will be useful for filling the needs of the local market and for the revegetation programs of the arid and semi-arid zones in Morocco.

Acknowledgments: We would like to show our gratitude to Pr. Sanah ESSAYEGH for her contribution in proofreading this article.

\section{REFERENCES}

Aliyu, B. S., \& Mustapha, Y. (2007). Effect of different media on the in vitro growth of cactus (Opuntia ficus-indica) explants. African Journal of Biotechnology, 6(11). doi: https://doi.org/10.5897/AJB2007.000-2185

Ault, J. R., \& Blackmon, W. J. (1987). In vitro propagation of Ferocactus acanthodes (Cactaceae). HortScience, 22, 126-127.

Boujghagh, M., \& Chajia, L. (2001). Le cactus: outil de gestion de la sécheresse dans le Sud Marocain. Terre et vie, 52, 1-7.

Boxus, P., \& Terzi, J. M. (1987). BIG LOSSES DUE TO BACTERIAL CONTAMINATIONS CAN BE AVOIDED IN MASS PROPAGATION
SCHEME. Acta Hortic. 212, 91-94.(212), 91-94.

doi https://doi.org/10.17660/ActaHortic.1987.212.12

Cassells, A. C. (1986). Production of healthy plants. Paper presented at the proceedings of the Institute of Horticultural Symposium: Micropropagation in culture, Nothingham.

Cassells, A. C. (1991). Problems in tissue culture: culture contamination. In P. C. Debergh \& R. H. Zimmerman (Eds.), Micropropagation: Technology and Application (pp. 31-44). Dordrecht: Springer Netherlands.

Clayton, P. W., Hubstenberger, J. F., Phillips, G. C., \& Butler-Nance, S. A (1990). Micropropagation of members of the Cactaceae subtribe Cactinae. Journal of the American Society for Horticultural Science, 115(2), 337-343. doi https://doi.org/10.21273/JASHS.115.2.337

Dabekaussen, M. A. A., Pierik, R. L. M., van der Laken, J. D., \& Hoek Spaans, J. (1991). Factors affecting areole activation in vitro in the cactus Sulcorebutia alba Rausch. Scientia Horticulturae, 46(3), 283-294. doi https://doi.org/10.1016/0304-4238(91)90051-Y

De Medeiros, L. A., de Ribeiro, R. C. S., Gallo, L. A., de Oliveira, E. T., \& Demattê, M. E. S. P. (2006). Invitro propagation of Notocactus magnificus. Plant Cell, Tissue and Organ Culture, 84(2), 165-169. doi https://doi.org/10.1007/s11240-005-9014-x

De Oliveira, S. A., da Silva, M. d. F. P., Prioli, A. J., \& Mangolin, C. A. (1995) In vitro propagation ofCereus peruvianus mill.(cactaceae). In Vitro Cellular \& Developmental Biology-Plant, 31(1), 47-50. doi https://doi.org/10.1007/BF02632226

Debergh, P. C., \& Vanderschaeghe, A. M. (1988). SOME SYMPTOMS INDICATING THE PRESENCE OF BACTERIAL CONTAMINANTS IN PLANT TISSUE CULTURES. Acta Hortic. 212, 91-94.(225), 77-82. doi 10.17660/ActaHortic.1988.225.8 https://doi.org/10.17660/ActaHortic. 1988.225.8 El Finti, A., El Boullani, R., Belayadi, M., Ait Aabd, N., \& El Mousadik, A. (2012). MICROPROPAGATION IN VITRO OF OPUNTIA FICUS-INDICA IN SOUTHERN MOROCCO. Acta Hortic. 212, 91-94.(995), 93-98. doi https://doi.org/10.17660/ActaHortic.2013.995.11

Escobar, A., Hugo, A., Villalobos, A., Víctor, M., Villegas, M., \& Angel. (1986). Opuntia micropropagation by axillary proliferation. Plant Cell, Tissue Organ Culture, 7(3), 269-277. doi: https://doi.org/10.1007/BF00037744

Estrada-Luna, A. A., Martínez-Hernández, J. d. J., Torres-Torres, M. E., \& Chablé-Moreno, F. (2008). In vitro micropropagation of the ornamental prickly pear cactus Opuntia lanigera Salm-Dyck and effects of sprayed GA3 after transplantation to ex vitro conditions. Scientia Horticulturae, 117(4), 378-385. doi: https://doi.org/10.1016/j.scienta.2008.05.042

Eugenio, P.-M.-B., \& Carlos Antonio, D.-F. (2002). In vitro propagation of Pelecyphora aselliformis Ehrenberg and P. strobiliformis Werdermann (cactaceae). In Vitro Cellular \& Developmental Biology - Plant, 38(1), 73-78. doi: https://doi.org/10.1079/IVP2001248

Felker, P., Paterson, A., \& Jenderek, M. M. (2006). Forage potential of Opuntia clones maintained by the USDA, National Plant Germplasm System (NPGS) collection. Crop science, 46(5), 2161-2168. doi: https://doi.org/10.2135/cropsci2006.02.0081

Flores-Valdez, C., A., \& Osorio-Gilberto, A. (1996). Opuntia-based ruminant feeding systems in Mexico. Grana, 56(150,000), 150-000.

García-Saucedo, P. A., Valdez-Morales, M., Elena Valverde, M., CruzHernández, A., \& Paredes-López, O. (2005). Plant regeneration of three Opuntia genotypes used as human food. Plant Cell, Tissue and Organ Culture, 80(2), 215-219. doi: https://doi.org/10.1007/s11240-004-9158-0

Ghaffari, A., Hasanloo, T., \& Nekouei, M. K. (2013). Micropropagation of tuna (Opuntia ficus-indica) and effect of medium composition on proliferation and rooting. International Journal of Biosciences, 3(11), 129-139. doi http://dx.doi.org/10.12692/ijb/3.11.129-139

Giusti, P., Vitti, D., Fiocchetti, F., Colla, G., Saccardo, F., \& Tucci, M. (2002). In vitro propagation of three endangered cactus species. Scientia Horticulturae, 95(4), 319-332. doi: https://doi.org/10.1016/S0304-4238(02)00031-6

Jaiswal, V. S., \& Amin, M. N. (1987). In Vitro Propagation of Guava from Shoot Cultures of Mature Trees. Journal of Plant Physiology, 130(1), 7-12. doi: https://doi.org/10.1016/S0176-1617(87)80296-1

Johnson, J. L., \& Emino, E. R. (1979). Tissue culture propagation in the Cactaceae. Cactus and Succulent Journal, 51, 275-277.

Juárez, M. C., \& Passera, C. B. (2002). In vitro propagation of Opuntia ellisiana Griff. and acclimatization to field conditions. Biocell : official journal of the Sociedades Latinoamericanas de Microscopia Electronica ... et. al, 26(3), 319324.

Karimi, N., Mofid, M. R., Ebrahimi, M., \& Naderi, R. (2010). Effect of areole and culture medium on callus induction and regeneration Cereus peruvianus Mill.(Cactaceae). Trakia Journal of Sciences, 8(2), 31-35.

Katja, G., Moebius-Goldammer., Martín, M.-R., \& Victor M, C.-A. (2003). Organogenesis and somatic embryogenesis in Ariocarpus kotschoubeyanus (Lem.) K. Schum. (Cactaceae), an endemic and endangered Mexican species. In Vitro Cellular \& Developmental Biology - Plant, 39(4), 388-393. doi: https://doi.org/10.1079/IVP2003427

Khalafalla, M. M., Abdellatef, E., Ahmed, M. M. M., \& Osman, M. G. (2007) Micropropagation of cactus (Opuntia ficus-indica) as strategic tool to combat 
desertification in arid and semi arid regions. International Journal of Sustainable Crop Production, 2(4), 1-8.

Le Houérou, H. N. (1992). The role of saltbushes (Atriplex spp.) in arid land rehabilitation in the Mediterranean Basin: a review. Agroforestry Systems, 18(2), 107-148. doi: https://doi.org/10.1007/BF00115408

Leifert, C., Ritchie, J. Y., \& Waites, W. M. (1991). Contaminants of plant-tissue and cell cultures. World Journal of Microbiology and Biotechnology, 7(4), 452469. doi: https://doi.org/10.1007/BF00303371

Leifert, C., \& Waites, W. M. (1990a). Bacteria and yeasts; important contaminants in micropropagated plant cultures. Abstracts VIIth International Congress on Plant Tissue and Cell Culture ed. NIJKAMP H.J.J., VAN DER PLAS L.H.W. \& VAN AARTRIJK J. p. 112 Dordrecht: Kluwer Academic Publishers.

Leifert, C., \& Waites, W. M. (1990b). Contaminants of plant tissue cultures World Journal of Microbiology and Biotechnology 7 60(1991), 452-469. doi: https://doi.org/10.1007/BF00303371

Mabrouk, A., Abbas, Y., Fakiri, M., Benchekroun, M., El Kharrassi, Y., El Antry-Tazi, S., \& El Mzouri, E. (2016). Caractérisation phénologique de différents écotypes de cactus (Opuntia spp.) Marocains sous les conditions édapho-climatiques de la région de Chaouia-Ouardigha (Phenological characterization among Moroccan ecotypes of cactus (Opuntia spp.) under soil and climatic conditions of the Chaouia-Ouardigha region). J. Mater. Environ. Sci, 7(4), 1396-1405.

Mace, G. M., Collar, N., Cooke, J., Gaston, K., Ginsberg, J., Leader-Williams, N., Milner-Gulland, E. J. (1992). The development of new criteria for listing species on the IUCN Red List. UK: Verlag nicht ermittelbar.

Martínez-Vázquez, O., \& Rubluo, A. (1989). In-vitro mass propagation of the near-extinct Mammillaria san-angelensis Sánchez-Mejorada. Journal of Horticultural Science, 64(1), 99-105. doi https://doi.org/10.1080/14620316.1989.11515933

Mohamed-Yasseen, Y., Barringer, S. A., Splittstoesser, W. E., \& Schnell, R. J. (1995). Rapid propagation of tuna (Opuntia ficus-indica) and plant establishment in soil. Plant Cell, Tissue and Organ Culture, 42(1), 117-119. doi: https://doi.org/10.1007/BF00037690

Murashige, T., \& Skoog, F. (1962). A revised medium for rapid growth and bio assays with tobacco tissue cultures. Physiologia plantarum, 15(3), 473-497. doi: https://doi.org/10.1111/j.1399-3054.1962.tb08052.x

Nobel, J. L. (1995). Changes in water potential and its component during shoot formation in cacti callus. Physiol. Plant, 45, 92-97.

Palomino, G., Dolezel, J., Cid, R., Brunner, I., Méndez, I., \& Rubluo, A. (1999). Nuclear genome stability of Mammillaria san-angelensis (Cactaceae) regenerants induced by auxins in long-term in vitro culture. Plant Science, 141(2), 191-200. doi: https://doi.org/10.1016/s0168-9452(98)00216-7

Pimienta-Barrios, E. (1994). Prickly pear (Opuntia spp.): A valuable fruit crop for the semi-arid lands of Mexico. Journal of Arid Environments, 28(1), 1-11. doi: https://doi.org/10.1016/S0140-1963(05)80016-3

Ramirez-Malagon, R., Aguilar-Ramirez, I., Borodanenko, A., Perez-Moreno, L., Barrera-Guerra, J. L., Nuñez-Palenius, H. G., \& Ochoa-Alejo, N. (2007). In vitro propagation of ten threatened species of Mammillaria (Cactaceae). In Vitro Cellular \& Developmental Biology - Plant, 43(6), 660-665. doi: https://doi.org/10.1007/s11627-007-9076-Z

Rubluo, A., Reyes, J., Rodriguez-Garay, B., Pimienta-Barrios, E., \& Brunner, I. (1996). Metodos de propagacion biotecnologicas y convencionales en cactaceas para zonas aridas. (J. Izquierdo \& G. Palomino Eds. Vol. 9). Santiago, Chile: FAO.

Scheinvar, L. (1995). Taxonomy of utilized Opuntias. In: Barbera G, Inglese P and Pimienta-Barrios E (Eds) Agroecology, cultivation and uses of cactus pear, FAO Plant Production and Protection Paper 132. Rome, Italy, p. 20-27.

Smith, R. H., Burdick, P. J., Anthony, J., \& Reilley, A. A. (1991). In vitro propagation of Coryphantha macromeris. HortScience, 26(3), 315-315. doi: https://doi.org/10.21273/HORTSCI.26.3.315 